\title{
BREEDING HERITAGE AND ITS ROLE IN STABILIZING PRODUCTION OF CORN GRAIN IN UKRAINE
}

\section{Lavrynenko Yu. O.}

\section{INTRODUCTION}

Providing the Earth's population with food is one of the global problems of the XXI century. It should be noted that at the beginning of a New era population of the Earth was 250-300 million and the population increase was quite slow. At the beginning of the XX century, the population of the world was 1.6 billion people, in $2010-7.0$ billion. In the world scale, agriculture is forced to increase grain production - the main food product for human, concentrated forage and the main source of plant proteins, carbohydrates and fats. Scientific forecasts testify that at significant increase of the population on the Earth, the production of food will not be in pace with such a growth and, according to the existing dynamics, the food problem may be escalated into the deep international $\mathrm{crisis}^{1,2}$.

Fig. 1 shows that the production of grain per capita grew synchronously with the growth of the population from 1960 to 1990 year. Since 1990 the increase in the provision of grain stabilized and it remains almost at the same level. Calculations show that at the current rate of population increase, in the future, the world grain production per person will be reduced. Therefore, humanity should find a solution to the problem, as population increase rates remain very high.

The nominee of the Nobel Prize, the author of «green revolution» Norman Borlaug, in his Nobel lecture made an important warning: «The green revolution provided only temporary success in the war of human against hunger and begging, it gave a temporary rest for human. In the full volume, the revolution can provide a sufficient amount of food for the next three decades. However, the threatening strength of the human reproduction

\footnotetext{
1 Мелик-Саркисов С. Щ. Биотехнология в аграрном секторе США: Экономика развития. М.: Всероссийский НИИ с.-х. биотехнологии РАСХН, 2005. 288 с.

2 Федорук П. С., Федорук С. П., Миренков С. Н. Проблемы и перспективы производства продуктов питания для народонаселения планеты. Научные труды Краснодарского НИИСХ им. П.П. Лукьяненко. Майкоп: Адыгея, 1999. С. 3-15.
} 
should also be limited, otherwise the success of the green revolution will be only ephemeral» ${ }^{3}$.

Threatening are the forecasts of reducing arable land area per capita, as the possibility of expanding agricultural land has almost been exhausted (Fig. 2). If at the beginning of the 20th century the population of the Earth was 1.8 billion people and the arable land area averaged to 0.72 ha per 1 person, then at the beginning of the 21 st century the area of arable land per 1 person decreased to 0.19 ha. Today, almost all land resources have been exhausted and the decrease in agricultural land due to the urbanization of territories and degradation of soils is going on. This indicates that the provision of human food is possible only by increasing the yield of plant production $^{4,5,6,7,8}$.

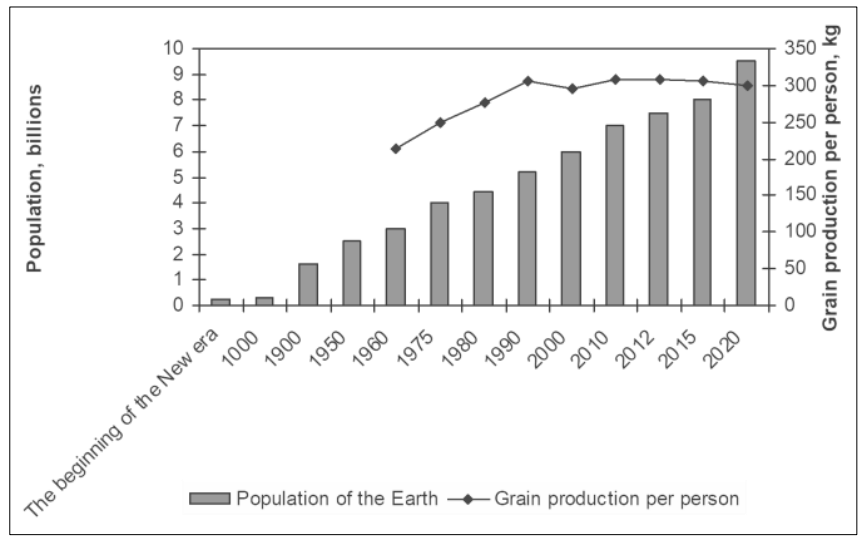

Fig. 1. World population dynamics on the Earth and grain production per person

${ }^{3}$ Nobel Lectures, Peace 1951-1970, Editor Frederick W. Haberman, Elsevier Publishing Company, Amsterdam, 1972 MLA style: «Norman Borlaug - Nobel Lecture: The Green Revolution, Peace, and Humanity».Nobelprize.org. Nobel Media AB 2013. Web. 9 Mar 2014. http://www.nobelprize.org/nobel_prizes/peace/laureates/1970/borlaug-lecture.html

${ }_{4}^{4}$ Джей Форрестер. Мировая динамика / Пер. с англ. А. Ворощука, С. Пегова. М.: ООО «Издательство АСТ; СПб.: Terra Fantastica, 2003. 379 с.

${ }^{5}$ Марфенин Н.Н. Устойчивое развитие человечества. М.: Изд-во МГУ, 2006. 612 с.

${ }^{6}$ Капица С. П. Демографическая революция и будущее человечества. В мире науки. 2004. №4. C. 82-91.

7 United Nations Population Division, World Health Organization (WHO), Food and Agriculture Organization (FAO), International Monetary Fund (IMF), and World Bank. http://www.worldometers.info/world-population/

${ }^{8}$ Народонаселение. Организация Объединенных Наций http://www.un.org/ru/sections/ issues-depth/population/ $\mathrm{OOH}$ 
Therefore, in the field of increasing productivity of grain crops (main source of foodstuffs), three main directions are possible: genetics-selection development; creation and improvement of agrotechnologies; optimization of allocation and specialization of production ${ }^{1,2}$.

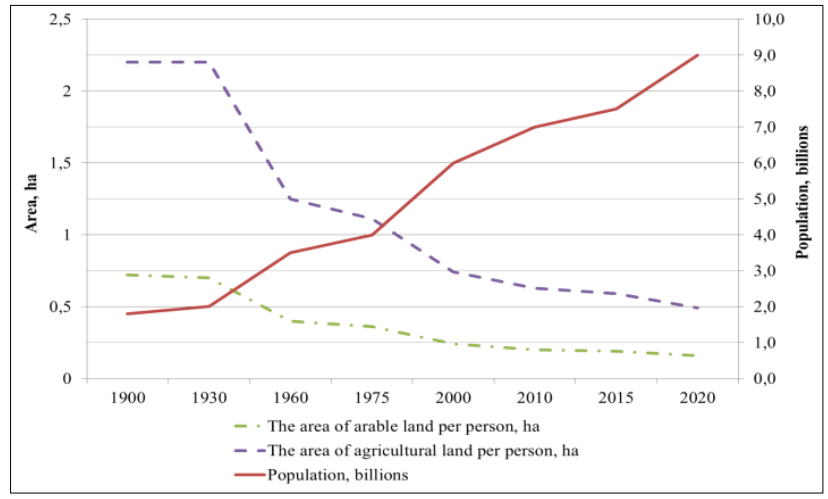

\section{Fig. 2. Projected area of arable land and agricultural lands, attributable to the population of the Earth}

For the whole thousand-years history of human civilization on the Earth, the main grains of mankind were wheat and rice. But at the beginning of the third millennium, the first place (by the gross harvest and yields) came to corn. For today, world corn production exceeds 1 billion tons of grain and in the coming years it is expected to increase of yields and gross harvest (Fig. 3).

As it is evident from the Figure 3, the gross harvest of rice and wheat have almost stabilized since the third millennium, but corn has a clear tendency to increase gross production. The main countries-producers are industrially developed, such the US, France, Italy or the dynamically developing countries - China, India, Romania, Brazil ${ }^{9} 10$.

The main increase of the world gross harvest of grain crops in 60-90-s was provided by the growth in yields (Fig. 4). This happened owing to the green revolution, which was launched by the Nobel Prize nominee Norman Borlaum for the introduction of new intensive wheat varieties and was spread in rice and corn.

\footnotetext{
${ }^{9}$ Food and Agriculture Organization of the United Nations http://www.fao.org/faostat/ en/\#data/QC ${ }^{9}$

${ }^{10}$ United States Department of Agriculture. Foreign Agricultural Service. http://www.usda crop explorer: global crop production analysis.
} 


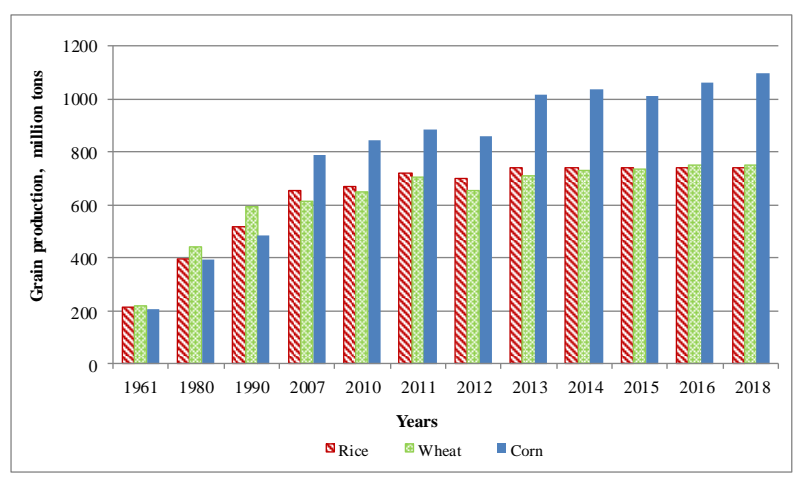

Fig. 3. The dynamics of the world's main grain crops production, million tons

This emphasizes the importance of the main direction in the productivity improvement - breeding and genetic development. By the testimony of the leading scientists, the increase in yield and gross harvest in recent years is possible owing to the breeding development by $50-80 \%{ }^{11} 12$.

That is why breeding developments of crops are actively engaged by scientists in the leading countries of the world.

The breeding of corn has made significant progress in the breeding centers of North America and European countries. This is evidenced by the fact that corn is consistently ahead by the yield for wheat and rice, which gave the impulse for increasing the sowing areas of these crops in the countries with dynamic development of agriculture.

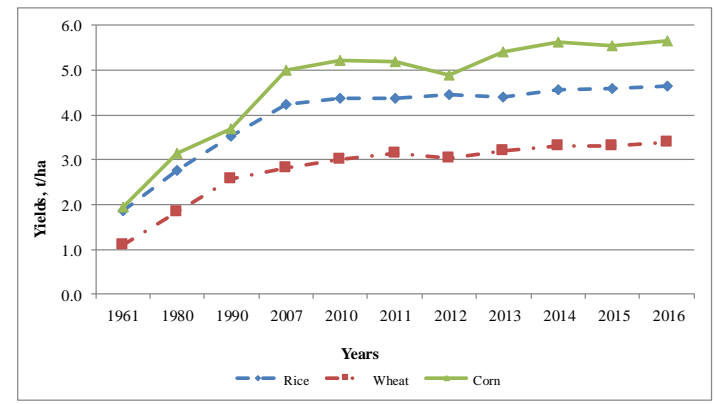

Fig. 4 The dynamics of the world yields of main grain crops, t/ha

\footnotetext{
${ }_{11}^{11}$ Созінов О. О. Нові рубежі в селекції рослин. Вісник аграрної науки. 2000. № 12. С. $22-24$.

${ }^{12}$ Рив М. Генетика и наследственность. М.: Мир, 1987. С. 251-276.
} 
Ukraine has intentions and opportunities to occupy an honorable place among the leading developed countries of the world by the economic indexes of the agrarian sector, and has already declared itself as a powerful producer and exporter of grain (Fig. 5). The rapid growth of corn production is due to the extremely high positive reactions to genetic shifts and technological developments. Breeders of Ukraine created corn hybrids with a certain level of adaptability to specific agro-ecological zones and technologies. The introduction of a new generation hybrids made it possible to increase the yield of grain over the past decade from 2.62 t/ha to 7.80 t/ha (Fig. 5).

By the yield of grain in 2018, Ukraine was ahead of the EU countries (Fig. 6). It should be noted that this crop is not yet in line with the potential capabilities of modern hybrids, but among the major global producers of corn, Ukraine takes the third position. Owing to the introduction of innovative hybrids, Ukraine entered into the six main producers of corn grain in the world and the top five exporters.

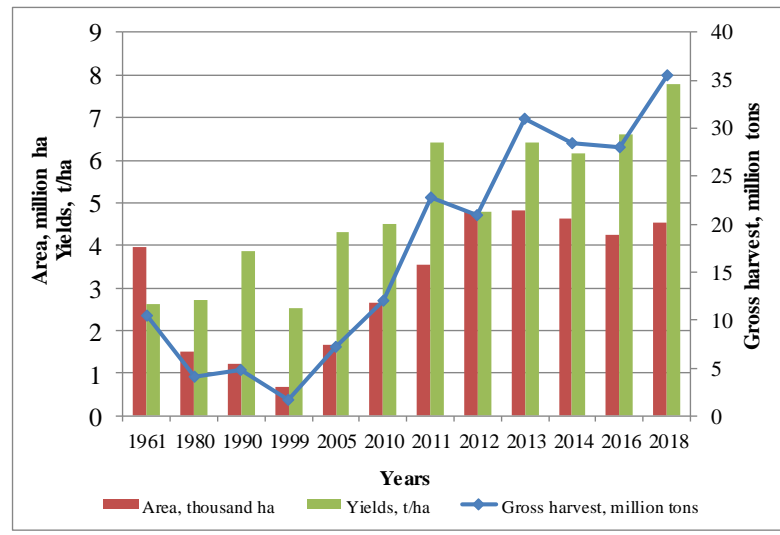

Fig. 5 Dynamics of corn grain production in Ukraine

Ukraine is one of the world's leading producers of corn grain, gross harvest exceeds 30 million tons ${ }^{9,10}$. The fundamental direction of the increase in corn yield is the introduction of hybrids of intensive type with low harvesting moisture that will provide an opportunity of spreading the areal of their use. 


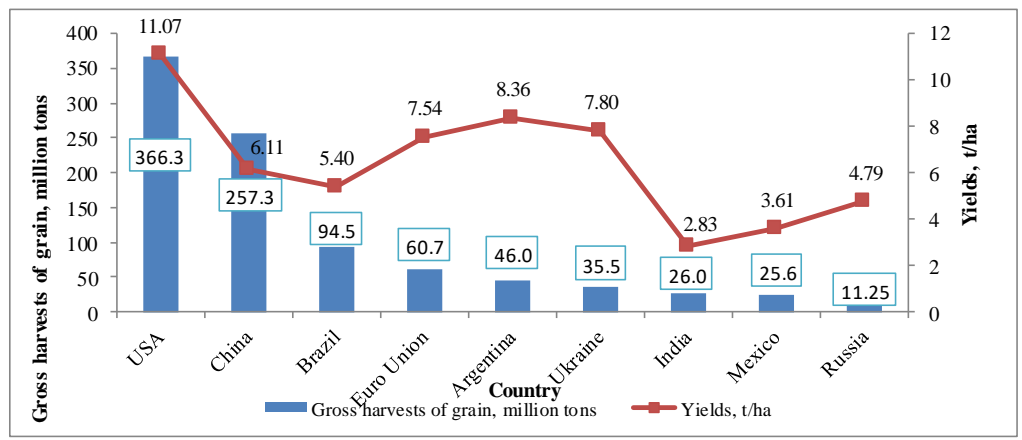

\section{Fig. 6 Gross harvest and yields of the world grain producers of corn (2018)}

The important role in the increase of yields and improvement of grain quality is played by the correct hybrids selection for cultivation. Highperformance hybrids uptake a large amount of nutrients from the soil, consume plenty of water, so such hybrids require appropriate agricultural technology. If such conditions are absent, the potentially more productive hybrid not only does not increase, but may provide a yield less than another less productive, but less demanding to the cultivation, hybrid ${ }^{13,14}$. So, we need differentiated approach to the selection of hybrids of the corresponding group of ripeness and purpose. To improve the implementation of the yield potential of modern hybrids, the development of morpho-physiological and heterobreeding models and hybrids selection on this basis with specific adaptability to agroecological factors is important ${ }^{15,16}$.

\section{Materials and methods of researches}

The accelerated obtaining of new varieties and hybrids, which are characterized by high and sustainable yields with the improved quality

\footnotetext{
${ }^{13}$ Munsch M. A., Stamp P., Christov N. K., Foueillassar X. M., Hüsken A., Camp K. H., Weider Ch. Grain Yield Increase and Pollen Containment by Plus-Hybrids Could Improve Acceptance of Transgenic Maize. Crop Science. 2010. Vol. 50, Iss. 3. P. 909-919.

${ }^{14}$ Vozhegova R. A., LavrinenkoYu. O., Hlushko T. V. Productivity of maize hybrids of different FAO groups depending on condition of irrigation and dosage of fertilizers in the southern steppe of Ukraine. Agricultural Science and Practice. 2014. Vol. 1. No. 3. P. 62-68.

${ }^{15}$ Troyer A. F. Background of U.S. hybrid corn: II. Breeding, climate and food. Crop Science. 2004. Vol. 44, Iss. 2. P. 370-380.

${ }^{16}$ Мустяца С. И., Мистрец С. И. Использование зародышевой плазмы гетерозисных групп БССС и Рейд Айодент в селекции скороспелой кукурузы. Кукуруза и сорго. 2007. № 6. С. $8-12$.
} 
indicators of grain, is assisted by the observance of a specific model of the crop in the process of creation and selection of appropriate genotypes. Model of variety includes both characteristics of productivity and characteristics indicating the relationship of the plant's body to the environmental elements. Developing an agricultural model requires information about the parameters of quantitative productivity indexes and their dependence on the indexes of morphology, physiology, specific adaptability, the combination ability of output lines and the application of appropriate heterosis plasms.

The task of the research was to develop morpho-physiological and heterosis models of corn hybrids and to create on their basis corn hybrids with FAO of 150-600 for the conditions of sufficient natural humidification and artificial irrigation with the yield of grain of.11,0-17.0 t/ha.

The research methods used: field, laboratory, statistical, selective genetic, retrospective.

The researches were performed during 2007-2017 in the Department of Plant Breeding of the Institute of Irrigated Agriculture of NAAS and Askanian State Research Station. The study was conducted with accordance to the relevant methodological requirements ${ }^{17,18}$.

\section{The results of the research}

The use of correlation-regression connections of quantitative productivity characteristics allowed to develop morpho-physiological and heterosis models of corn hybrids and to create on their basis corn hybrids with FAO of 150-600 for the conditions of artificial irrigation with grain yield of 11.0$17.0 \mathrm{t} / \mathrm{ha}$. The models of corn hybrids of five groups of ripeness were developed: the early ripening (FAO 150-190), the middle-early ripening (FAO 200-290), the middle ripening (FAO 300-390), the middle-late ripening (FAO 400-490), the late ripening (FAO 500-600), which corresponded to the requirements of adaptability to the conditions of irrigation (Table. 1).

The most stable in the conditions of southern region were the hybrids of the early ripening group of FAO 150-190, which are used for cultivation in post-mowing, post-harvest crops and as a fore-crop for winter crops. The potential yield of this group is considerably lower than of the late ripening one due to the reduced duration of the vegetative period. The model of the early ripening group hybrids of corn in the conditions of irrigated agriculture

17 Домашнев П. П., Дзюбецкий Б. В., Костюченко В. И. Селекция кукурузы. М.: Агропромиздат, 1992. 204 с.

${ }_{18}$ Ушкаренко В. А., Лазарев Н. Н., Голобородько С. П., Коковихин С. В. Дисперсионный и корреляционный анализ в растениеводстве и луговодстве. Москва: Изд-во РГАУ - МСХА имени К. А. Тимирязева, 2011. 336 с. 
should have genetic potential of grain yield at $10.5-11.5 \mathrm{t} / \mathrm{ha}$ under the optimal technological conditions of growing (see Table 1).

The South of Ukraine is characterized in the recent years by the fact that most of its territory is under the cultivation of the corn hybrids of the middle-early ripening group of FAO 200-290. The genotypes of this group have high potential yield, the vegetation period lasts in the South Steppe for 100-110 days, they are undemanding to agrotechnical support, resulting in a guaranteed ripening every year. Under the optimal conditions of cultivation and in compliance with the technology of cultivation corn hybrids of middleearly group of ripeness should have the yield of grain within 11.5-12.5 t/ha, grain outlet $-88-90 \%$, weight of grain per cob $-200-240 \mathrm{~g}$, weight of 1000 seeds $-270-310 \mathrm{~g}$ (see Table 1 ).

Table 1

Morpho-physiological parameters of the models of corn hybrids of FAO 150-600 for the conditions of irrigation in the South of Ukraine (2009-2015)

\begin{tabular}{|c|c|c|c|c|c|}
\hline Indicators & $\begin{array}{c}\text { FAO } \\
\mathbf{1 5 0 - 1 9 0}\end{array}$ & $\begin{array}{c}\text { FAO } \\
\mathbf{2 0 0 - 2 9 0}\end{array}$ & $\begin{array}{c}\text { FAO } \\
\mathbf{3 0 0 - 3 9 0}\end{array}$ & $\begin{array}{c}\text { FAO } \\
\mathbf{4 0 0 - 4 9 0}\end{array}$ & $\begin{array}{c}\text { FAO0-600 } \\
\mathbf{5 0 0}\end{array}$ \\
\hline Yield of grain, t/ha & $10.5-11.5$ & $11.5-12.5$ & $12.5-14.5$ & $14.5-17.0$ & $16.0-18.0$ \\
\hline $\begin{array}{c}\text { Harvesting moisture } \\
\text { of grain, \% }\end{array}$ & $12-13.0$ & $12.0-13.0$ & $13.5-14.0$ & $87-90$ & $85-88$ \\
\hline Grain yield, \% & $87-90$ & $87-90$ & $88-90$ & $240-260$ & $270-290$ \\
\hline Grain weight per cob, g & $180-200$ & $200-240$ & $220-240$ & $13.5-14.5$ & $16-18$ \\
\hline Weight of 1000 seeds, g & $250-280$ & $270-310$ & $280-320$ & $300-320$ & $300-340$ \\
\hline Length of the cob (full), cm & $16,0-18,0$ & $18-20$ & $20-21$ & $20-23$ & $20-24$ \\
\hline $\begin{array}{c}\text { Length of the cob } \\
\text { with grain, cm }\end{array}$ & $16.0-18.0$ & $18-20$ & $20-21$ & $19.5-22.0$ & $20-24$ \\
\hline Diameter of the cob, cm & $4.2-4.5$ & $4.5-4.8$ & $4.6-5.0$ & $5.0-5.2$ & $5.5-5.7$ \\
\hline Number of rows, pcs & $14-16$ & $14-16$ & $16-18$ & $18-22$ & $18-24$ \\
\hline Number of grains, pcs & $40-45$ & $42-45$ & $46-48$ & $48-50$ & $46-52$ \\
\hline Core diameter, cm & $2.0-2.3$ & $2.3-2.4$ & $2.4-2.8$ & $2.4-2.6$ & $2.6-2.8$ \\
\hline $\begin{array}{c}\text { Photosynthetic potential, } \\
\text { thousanf } \text { m }^{2 *} \text { days }\end{array}$ & 1500 & 2500 & 2950 & 3200 & 3500 \\
\hline Leaf area index (LAI) & 3.8 & 5.0 & 5.6 & 6.0 & 6.0 \\
\hline
\end{tabular}

The main element of cost-effective production of middle-ripening hybrids is the harvesting by the direct threshing, which provides saving of funds for drying, due to low harvesting moisture of grain. For this purpose, it is especially important to create a morpho-physiological model of the middle-ripening corn group of FAO 300-390 (see Table 1). Hybrids of the middle-ripening model of corn hybrids are high-yielding, this is testified by the high productivity indexes: grain yield is $12.5-14.5 \mathrm{t} / \mathrm{ha}$, grain outlet $88.0-90.0 \%$, weight of grain per cob - 220-240 g, weight of 1000 seeds 280-320 g. The corn hybrids of this group of ripeness should have the potential to form plants with two cobs. 
The development of heterosis model and the use of modern germplasm is an important factor of effective plant breeding ${ }^{19}$. The creation of fundamentally new adaptive hybrids of corn requires the use of traditional heterosis models and creation of new elite lines based on the mixed germ plasm, formed on the basis of new industrial hybrids. The analysis of usage of the basic germ plasma in recent years has shown that, along with traditional heterosis groups, the number of the lines created on the basis of new commercial hybrids, the so-called «mixed plasma», is increasing (Table. 2). It should be noted that the major germ plasma has survived today in working collections in a rather modified condition, and it is sometimes possible to obtain hybrids with a sufficiently high level of contest heterosis and within a single source plasma.

Table 2

The use of the lines of basic germ plasma in the hybrids of corn of the contest variety-testing with FAO 150-390 (2007-2015)

\begin{tabular}{|c|c|c|c|c|c|c|}
\hline \multirow{2}{*}{$\begin{array}{c}\text { Origin of the } \\
\text { input material }\end{array}$} & \multicolumn{7}{|c|}{ FAO 150-200 } & \multicolumn{2}{c|}{ FAO 200-290 } & \multicolumn{2}{c|}{ FAO 300-390 } \\
\cline { 2 - 7 } & $\begin{array}{c}\mathbf{2 0 0 7 -} \\
\mathbf{2 0 1 0}\end{array}$ & $\begin{array}{c}\mathbf{2 0 1 1 -} \\
\mathbf{2 0 1 5}\end{array}$ & $\begin{array}{c}\mathbf{2 0 0 7 -} \\
\mathbf{2 0 1 0}\end{array}$ & $\begin{array}{c}\mathbf{2 0 1 1 -} \\
\mathbf{2 0 1 5}\end{array}$ & $\begin{array}{c}\mathbf{2 0 0 7 -} \\
\mathbf{2 0 1 0}\end{array}$ & $\begin{array}{c}\mathbf{2 0 1 1 -} \\
\mathbf{2 0 1 5}\end{array}$ \\
\hline Lakaune & 22.4 & 12.7 & 4.5 & 6.3 & 0.8 & 0.5 \\
\hline S72 & 18.0 & 8.7 & 3.2 & - & - & - \\
\hline P502 & 14.3 & 9.5 & 17.6 & 8.6 & 4.3 & 2.3 \\
\hline P346 & - & - & 16.7 & 7.5 & 0.7 & - \\
\hline Lancaster (OH43) & 13.5 & 18.4 & 5.3 & 13.2 & 18.9 & 15.4 \\
\hline Lancaster (C103) & - & - & - & - & - & 2.7 \\
\hline Raid (WF9) & 24.6 & 25.3 & 23.6 & 27.8 & 8.4 & 7.4 \\
\hline Raid (SSS) & - & - & - & - & - & 2.3 \\
\hline Aiodent & - & 9.8 & 15.3 & 23.4 & 38.6 & 41.1 \\
\hline T 22 & - & - & 5.2 & 0.7 & 7.5 & - \\
\hline Other & - & - & 5.6 & 2.0 & 3.1 & 2.8 \\
\hline Mixed plasma & 7.2 & 15.6 & 3.0 & 10.5 & 17.7 & 25.5 \\
\hline
\end{tabular}

The corn hybrids of the middle-late (FAO 400-490) and late (FAO 500600 ) ripeness group have the highest productivity potential. However, this group of ripeness until now did not always meet the requirements of modern technologies of cultivation, associated with the grain harvesting by combines with direct threshing and required harvesting moisture at the level of 13$16 \%$. The models of such high-productive hybrids and self-pollinated paternal lines have been developed, meeting the requirements concerning the technological cultivation of corn in the conditions of irrigation.

19 Дзюбецький Б. В., Черчель В. Ю. Сучасна зародкова плазма в програмі з селекції кукурудзи в Інституті зернового господарства УААН. Селекція і насінництво. Харків, 2002. № 86. С. 11-19. 
In the developed model of the middle-late group (FAO 400-490) the following quantitative characteristics have been formed that formed the grain yield at the level of 14-17 t/ha. Grain weight per cob is 240-260 g, weight of 1000 seeds $-300-320 \mathrm{~g}$, grain outlet $-87-90 \%$. The cob is of medium size, the 3 full length $-20-23 \mathrm{~cm}$, length of the cob with grain $-19.5-22.0 \mathrm{~cm}$. The main structural elements of the cob had the following characteristics: the diameter of the cob $-5.0-5.2 \mathrm{~cm}$, the core diameter $-2.4-2.6 \mathrm{~cm}$, the core is red. The cob is cylindrical. Photosynthetic potential is 3200 thousand $\mathrm{m}^{2}$ *day, leaf area index -6.0 (Table 1).

The corn hybrids of the late ripening group by FAO are the most productive in the South of Ukraine under the obligatory presence of irrigation. However, it should be noted that the hybrids of corn with FAO 500-600 not every year can form a ripe grain because of the insufficient number of effective temperatures and cool wet autumn. Studies have established that in the third decade of September and October, the drying of the grain is significantly delayed and it is not $1.2-1.5 \%$ as in August - the first half of September, and decreases to $0.1-0.5 \%$ (secondary humidifying of grain in rainy weather can occur) ${ }^{20}$. Therefore, cultivation of the corn hybrids of late group of ripeness is associated with certain risk for production. The following parameters of the morpho-physiological model of the corn hybrids of late group are determined - the yield of grain of 16-18 $\mathrm{t} / \mathrm{ha}$, the grain outlet $-85-88 \%$. The average value of a grain weight per cob is $270-290 \mathrm{~g}$ (see Table 1 ).

Analysis of usage in the recent years of the basic germ plasma of FAO 400-600 has shown that the share of the lines created on the basis of new synthetic populations (mixed plasma) is increased along with traditional heterosis groups (Table 3). The line of plasma Raid (SSS) and Lancaster (C103) underwent a significant selection revision, mainly in the direction of the speeding up the loss of moisture at the ripening period.

This is especially true for the group of lines with FAO more than 500 . So, if the base lines X18, B73, X18-1, X902 (parental forms of hybrids Perekop, Borysfen 600) provided the level of grain yield up to $15 \mathrm{t} / \mathrm{ha}$, however, the harvesting moisture of the grain was at the level of $25-30 \%$ that is unacceptable for modern corn cultivation technologies. Besides, the hybrids with FAO of 500-600 are very sensitive to the technological conditions of cultivation and the slightest disruption of the technological regulations leads to drastic decrease in yield, which eliminates their potential and leads to economic losses. That is why, selection of hybrids with FAO

\footnotetext{
${ }^{20}$ Плоткін С. Я., Лазер П. Н., Йокич Д. Р. Еколого-генетична детермінація добової втрати вологи зерном при дозріванні у гібридів кукурудзи в умовах південного Степу. Таврійський науковий вісник. 2003. Вип. 26. С. 37-45.
} 
500-600 in the conditions of irrigation of the South of Ukraine today has little prospects and is held in a limited volume.

Table 3

The use of lines of basic germ plasma in the hybrids of corn of the contest variety-testing of FAO 400-600 (2007-2015)

\begin{tabular}{|c|c|c|c|c|}
\hline \multirow{2}{*}{$\begin{array}{c}\text { Origin of the input } \\
\text { material }\end{array}$} & \multicolumn{4}{|c|}{ Ripeness group by FAO } \\
\cline { 2 - 5 } & \multicolumn{2}{|c|}{ FAO 400-490 } & \multicolumn{2}{c|}{ FAO 500-600 } \\
\cline { 2 - 5 } & $\mathbf{2 0 0 7 - 2 0 1 0}$ & $\mathbf{2 0 1 1 - 2 0 1 5}$ & $\mathbf{2 0 0 7 - 2 0 1 0}$ & $\mathbf{2 0 1 1 - 2 0 1 5}$ \\
\hline Lancaster (OH43) & 11.5 & 5.6 & - & - \\
\hline Lancaster (C103) & 15.6 & 14.8 & 8.3 & 6.3 \\
\hline Raid (WF9) & 2.3 & 1.5 & - & - \\
\hline Raid (SSS) & 17.8 & 14.2 & 45.6 & 44.7 \\
\hline Aiodent & 36.9 & 33.1 & - & - \\
\hline Other & 1.2 & 1.5 & 2.3 & 1.2 \\
\hline Mixed plasma & 14.7 & 29.3 & 43.8 & 47.8 \\
\hline
\end{tabular}

The main germ plasma has survived today in working collections in a rather modified condition, and sometimes it is possible to obtain hybrids with a sufficiently high level of contest heterosis and within a single source plasma.

It is typical that among the linear material of FAO 400-490 there is a fairly large range of original elite material, which provides for hybrid combinations with a programmed level of yield, however, the elite material input material of the group of FAO 500-600 islvery Limited. This is due to the fact that the selection of hybrids with FAO more than 500 is limited in the main plant breeding institutions of Ukraine and Europe, which is primarily due to the high expenditures for grain drying.

The formation of the maximum yield of a hybrid depends on a number of factors, one of which is the cultivation zone, where the resources of the environment correspond to the biological optimum of the genotype. For each region, there are their optimum models of new corn hybrids and in accordance with this, plant breeding work is carried out. On the basis of the developed models, in the cooperation between the Institute of Irrigated Agriculture and the Institute of Cereal Crops of NAAS, new hybrids of corn having the adaptation to the conditions of irrigation, various irrigation regimes, an adequate projected response to the technological support and high productivity potential were created.

Modern hybrids of corn, created for irrigated conditions, has to be transferred to production with certain parameters of technological requirements, and especially for irrigation regimes and ways of irrigation. The studies, which were carried out on different irrigated arrays, various 
ways of irrigation and irrigation regimes, provided an opportunity to provide the production the adaptation parameters for the certain hybrids to specific agro-ecological and technological peculiarities. In the Table 4, the productivity of modern corn hybrids, created for irrigated conditions, depending on the way of irrigation and water supply regime on the main irrigated arrays of the South of Ukraine is presented.

Table 4

Grain yield (t/ha) of corn hybrids at various ways of irrigation and irrigation regimes (2016-2017)

\begin{tabular}{|c|c|c|c|c|c|}
\hline Hybrid & FAO & $\begin{array}{c}\text { Watering } \\
\text { with } \\
\text { sprinkler } \\
\text { machine } \\
\text { DDA 100 } \\
\text { MA, } \\
\text { Ingulets } \\
\text { irrigated } \\
\text { array, TAW } \\
\text { at } 70 \% \text { FC } \\
\end{array}$ & $\begin{array}{c}\text { Watering } \\
\text { with drip } \\
\text { irrigation, } \\
\text { Ingulets } \\
\text { irrigated } \\
\text { array, TAW } \\
\text { at } 80 \% \text { FC }\end{array}$ & $\begin{array}{c}\text { Watering } \\
\text { with drip } \\
\text { irrigation, } \\
\text { Ingulets } \\
\text { irrigated } \\
\text { array, TAW } \\
\text { at } 85 \% \text { FC }\end{array}$ & $\begin{array}{c}\text { Watering } \\
\text { with } \\
\text { sprinkler } \\
\text { machine } \\
\text { Zimmatic, } \\
\text { Kakhovka } \\
\text { irrigated } \\
\text { array, TAW } \\
\text { at } 80 \% \text { FC }\end{array}$ \\
\hline DN Pivikha & 190 & 9.31 & 10.16 & 11.02 & 10.73 \\
\hline Tendra & 190 & 8.83 & 9.25 & 10.46 & 9.90 \\
\hline Oberig & 190 & 9.86 & 10.22 & 11.37 & 10.74 \\
\hline DN Hawtin & 250 & 10.56 & 12.44 & 13.07 & 12.83 \\
\hline DN Galateya & 250 & 10.43 & 11.90 & 13.15 & 12.36 \\
\hline $\begin{array}{c}\text { Orzhytsya } \\
237 \mathrm{MV}\end{array}$ & 250 & 9.54 & 10.73 & 10.90 & 10.54 \\
\hline Korund & 280 & 10.15 & 11.61 & 13.51 & 12.43 \\
\hline Skadovskyi & 280 & 10.82 & 11.05 & 11.94 & 11.48 \\
\hline DN Rostock & 300 & 8.96 & 12.34 & 14.64 & 12.42 \\
\hline DN Demetra & 300 & 8.77 & 12.04 & 13.33 & 12.11 \\
\hline DN Aquazor & 320 & 9.64 & 12.45 & 14.17 & 12.10 \\
\hline DN Zbruch & 350 & 9.16 & 12.36 & 14.48 & 12.59 \\
\hline DN Vizyr & 350 & 8.95 & 12.07 & 13.23 & 12.65 \\
\hline Kakhovskyi & 350 & 8.90 & 13.01 & 13.17 & 12.74 \\
\hline Azov & 380 & 8.13 & 12.18 & 13.34 & 13.16 \\
\hline DN Bereka & 390 & 9.50 & 13.63 & 15.28 & 14.17 \\
\hline DN Hetera & 420 & 8.32 & 14.48 & 17.14 & 13.77 \\
\hline DN Anshlag & 420 & 8.93 & 15.03 & 17.43 & 13.71 \\
\hline DN Rawa & 420 & 8.54 & 14.82 & 16.85 & 14.42 \\
\hline Arabat & 430 & 7.98 & 16.40 & 17.81 & 14.34 \\
\hline Prymorskyi & 420 & 8.04 & 14.35 & 15.47 & 13.17 \\
\hline Chonhar & 430 & 8.91 & 14.03 & 14.42 & 13.44 \\
\hline $\mathrm{LSD}_{05}$ & & 0.31 & 0.42 & 0.41 & 0.34 \\
\hline
\end{tabular}

To set the norm of the reaction for newly created hybrids depending on the technological conditions, we investigated the influence of such irrigation 
ways and regimes: watering with sprinkler irrigation machine DDA $100 \mathrm{MA}$ at Ingulets irrigated array with a level of soil moisture content of $70 \%$ FC (TAW at $70 \%$, water-saving mode); watering with drip irrigation, Ingulets irrigated array, TAW moisture content at $80 \%$ FC; drip irrigation, Ingulets irrigated array, TAW soil moisture at $85 \%$ FC (optimal regime); watering with irrigation machine Zimmatic, Kakhovka irrigated array, TAW soil moisture at $80 \% \mathrm{FC}$.

It is determined that the hybrids with FAO 190 have sustainable yield indexes at different regimes of irrigation. Use of these hybrids is advisable for the water-saving regimes of irrigation on the irrigated lands with a low hydro-module capacity.

The best in the indexes of yield plasticity among the hybrids of middleearly group of ripeness (FAO 190-280) was hybrid Hawtin (FAO 250), independently on the way of irrigation. Thus, watering in the area of the Ingulets irrigated array, there was the yield at the level of $10.56 \mathrm{t} / \mathrm{ha}$, and at the cultivation in the zone of the Kakhovka irrigation system $-12.83 \mathrm{t} / \mathrm{ha}$. It became the best in his group of ripeness at the cultivation under the drip irrigation with TAW soil moisture at the level of 80 and $85 \%$ FC, where the yield of hybrid Hawtin was 12.44 and 13.07 t/ha. For the use of TAW soil moisture at $85 \% \mathrm{FC}$, the best among the early ripening and middle-early hybrids of corn was the hybrid Korund $-13.51 \mathrm{t} / \mathrm{ha}$.

Among the middle-ripening hybrids (FAO 300-390) at the irrigation within the Ingulets array, the strong reaction of hybrids to the ecological gradient of cultivation was observed. Yield of the hybrids of this type drastically decreases at the use of water-saving irrigation regimes. These hybrids belong to the intensive type and dramatically reduce the yield of grain below the level of the hybrids with FAO 190-280. It is not reasonable to use them at water-saving irrigation regimes, and it can lead to the yield losses. Genotypical capacity of the productivity of these hybrids can be opened only under the conditions of intensive technologies. At the TAW at $85 \%$ FC and drip irrigation, the yield of grain of the hybrids DN Aquazor, DN Bereka, DN Zbruch, DN Rostock reached 14-15 t/ha.

In the group of middle-late hybrids there are domestic corn hybrids of the intensive type Arabat, DN Hetera, DN Anshlag, DN Rawa, which provide the yield of grain of 15-17 t/ha at drip irrigation and sprinkler irrigation in the conditions of Ingulets and Kakovka irrigated arrays independently on the water quality. It is unreasonable to use the hybrids of this at the irrigated lands with a low hydro-module capacity and water-saving regimes, as this technology leads to significant losses of yield and they become noncompetitive with modern hybrids of FAO 190-280. These hybrids are not 
worse in grain yield to the best world analogues and have a predictable reaction on the level of technological support. This allows providing the production with not only domestic selective product, but at the same time the varietal technology, which is oriented on the soil-ecological zone, hydromodule capacity, crop rotation structure, the level of financial support of the farm.

The plastic hybrids of corn of the FAO 180-290 group Pivikha, Khotyn, Skadovskyi, which provide the level of grain yield of 8-9 t/ha under the use of water-saving irrigation regime, save irrigation water volumes within 30$35 \%$, and which are good fore-crops for winter cereals, for use of the sprinkler irrigation way on the systems with limited hydro-module capacity, are determined.

Thus, the production is proposed to use modern domestic corn hybrids of the intensive type Arabat, Anshlag, Hetera, Zbruch, Azov, Rostock at drip irrigation and sprinkler irrigation using TAW level at $80-85 \%$ FC, which provides the grain yield of 15-17 t/ha.

At the use of sprinkler irrigation method in the zones with a limited hydro-module capacity, which does not allow increasing TAW level more than of 70\%, it is necessary to use plastic hybrids of the FAO groups 180290 DN Pivikha, Khotyn, Korund, Sadovskyi, Solonianskyi 298SV, which provide grain yield level of 9-10 t/ha at the use of water-saving regime of irrigation, saving irrigation water volumes within $1200-1500 \mathrm{~m}^{3} / \mathrm{ha}$, and which are good fore-crops for winter cereal crops because of the early terms of harvesting in the third decade of August.

Summarizing the results of the corn selection for the irrigated conditions, it is possible to draw conclusions that universal hybrids adapted to a wide range of environmental conditions are inferior in productivity to the genotypes of narrow adaptability on every agroecological. By the adaptive properties we have to distinguish: the hybrids of the intensive type with strongly expressed reaction to the environment; homeostatic, which provide sustainable yields under the fluctuations of cultivation conditions; plastic, which adequately react to the changes of the level of agro-background.

To select for the adaptability, an ecological gradient, objectively reflecting the spectrum of agroecological conditions in the presumed region of the distribution of the corn hybrid, should be provided.

To obtain high and sustainable grain yield in every farm of the irrigated zone of the Steppe of Ukraine, it is obliged to have a specter of hybrids that have different type of reaction to changing environment: the intensive type to obtain the maximum yields on the best irrigated fields; homeostatic - to obtain guaranteed yield on the worse and rain-fed fields; moderately plastic with wide adaptive potential - to obtain relatively sustainable yield in the 
fields with an unstable agro-background (fields with a low hydro-module capacity of irrigation system).

\section{CONCLUSIONS}

In the conditions of irrigation, it is necessary to use corn hybrids with a genetically predicted reaction to the optimal cultivation conditions (optimal regime of soil moisture and mineral nutrition). Violation of cultivation technology leads to significant losses of grain yields, especially in the hybrids of the late ripening group. With the use of the developed morphobiological and heterosis model, it was possible to create corn hybrids of the intensive type with programmed parameters, which could be used in different agro-climatic zones and to realize the programmed grain yield.

Hybrids of the intensive type have a complex of economic and valuable characteristics, can form high yields at the level of 11-17 t/ha of grain under the efficient use of irrigation water, mineral macro- and micronutrient fertilizers, rapidly get rid of moisture at the ripening stage, have high resistance against common diseases and insects.

\section{SUMMARY}

Goal. To develop morpho-physiological and heterosis model of corn hybrids with FAO 150-600 for the irrigated conditions. Methods. General scientific, special genetic, field and laboratory and comparative methods of research were used. Results. The results of perennial researches on the development of morpho-physiological and heterosis models of corn hybrids of different groups of ripeness in the conditions of irrigation are presented. The main parameters of corn hybrids models of different groups by FAO. The parameters of heterosis models and of the created lines with high combinatory ability, which are involved in the genotype of newly created hybrids of the early-ripening, middle-early, middle-ripening, middle-late and late-ripening groups of maturity are determined. The results of the reaction of new hybrids on the irrigation ways and irrigation regimes are provided. Conclusions. Morpho-physiological and heterosis models and created on their basis corn hybrids of FAO 150-600 for the irrigated conditions in the South of Ukraine with grain yield of 11-17 t/ha were developed. New innovative hybrids of corn with FAO of 150-600 for the irrigated conditions, which have a complex of economically valuable characteristics and can form high yields at irrigation (11-17 t/ha of grain) under the efficient use of irrigation water, mineral macro- and micronutrient fertilizers, rapidly getting rid of grain moisture at the stage of ripening, and highly resistant to the common diseases and insects, which is put into their genetic potential. 


\section{REFERENCES}

1. Мелик-Саркисов С. Щ. Биотехнология в аграрном секторе США: Экономика развития. М.: Всероссийский НИИ с.-х. биотехнологии PACXH, 2005. $288 \mathrm{c}$.

2. Федорук П. С., Федорук С. П., Миренков С. Н. Проблемы и перспективы производства продуктов питания для народонаселения планеты. Научные труды Краснодарского НИИСХ им. П.П. Лукьяненко. Майкоп: Адыгея, 1999. С. 3-15.

3. Nobel Lectures, Peace 1951-1970, Editor Frederick W. Haberman, Elsevier Publishing Company, Amsterdam, 1972 MLA style: «Norman Borlaug - Nobel Lecture: The Green Revolution, Peace, and Humanity». Nobelprize.org. Nobel Media AB 2013. Web. 9 Mar 2014. http://www.nobelprize.org/nobel_prizes/peace/laureates/1970/borlauglecture.html

4. Джей Форрестер. Мировая динамика / Пер. с англ. А.Ворощука, С.Пегова. М.: ООО «Издательство АСТ; СПб.: Terra Fantastica, 2003. $379 \mathrm{c}$.

5. Марфенин Н.Н. Устойчивое развитие человечества. М.: Изд-во МГУ, 2006. $612 \mathrm{c.}$

6. Капица С. П. Демографическая революция и будущее человечества. В мире науки. 2004. №4. С. 82-91.

7. United Nations Population Division, World Health Organization (WHO), Food and Agriculture Organization (FAO), International Monetary Fund (IMF), and World Bank. http://www.worldometers.info/worldpopulation/

8. Народонаселение. Организация Объединенных Наций http://www.un.org/ru/sections/issues-depth/population/ OOH

9. Food and Agriculture Organization of the United Nations http://www.fao.org/faostat/en/\#data/QC

10. United States Department of Agriculture. Foreign Agricultural Service. http://www.usda crop explorer: global crop production analysis

11. Созінов О. О. Нові рубежі в селекції рослин. Вісник аграрної науки. 2000. №12. С. 22-24.

12. Рив М. Генетика и наследственность. М.: Мир, 1987. С. 251276.

13. Munsch M. A., Stamp P., Christov N. K., Foueillassar X. M., Hüsken A., Camp K. H., Weider Ch. Grain Yield Increase and Pollen Containment by Plus-Hybrids Could Improve Acceptance of Transgenic Maize. Crop Science. 2010. Vol. 50, Iss. 3. P. 909-919. 
14. Vozhegova R. A., LavrinenkoYu. O., Hlushko T. V. Productivity of maize hybrids of different FAO groups depending on condition of irrigation and dosage of fertilizers in the southern steppe of Ukraine. Agricultural Science and Practice. 2014. Vol. 1. No. 3. P. 62-68.

15. Troyer A. F. Background of U.S. hybrid corn: II. Breeding, climate and food. Crop Science. 2004. Vol. 44, Iss. 2. P. 370-380.

16. Мустяца С. И., Мистрец С. И. Использование зародышевой плазмы гетерозисных групп БССС и Рейд Айодент в селекции скороспелой кукурузы. Кукуруза и сорго. 2007. №6. С. 8-12.

17. Домашнев П. П., Дзюбецкий Б. В., Костюченко В. И. Селекция кукурузы. М.: Агропромиздат, 1992. 204 с.

18. Ушкаренко В. А., Лазарев Н. Н., Голобородько С. П., Коковихин С. В. Дисперсионный и корреляционный анализ в растениеводстве и луговодстве. Москва: Изд-во РГАУ - МСХА имени К. А. Тимирязева, 2011. 336 с.

19. Дзюбецький Б. В., Черчель В. Ю. Сучасна зародкова плазма в програмі з селекції кукурудзи в Інституті зернового господарства УААН. Селекція і насінництво. Харків, 2002. № 86. С. 11-19.

20. Плоткін С. Я., Лазер П. Н., Йокич Д. Р. Еколого-генетична детермінація добової втрати вологи зерном при дозріванні у гібридів кукурудзи в умовах південного Степу. Таврійський науковий вісник. 2003. Вип. 26. С. 37-45.

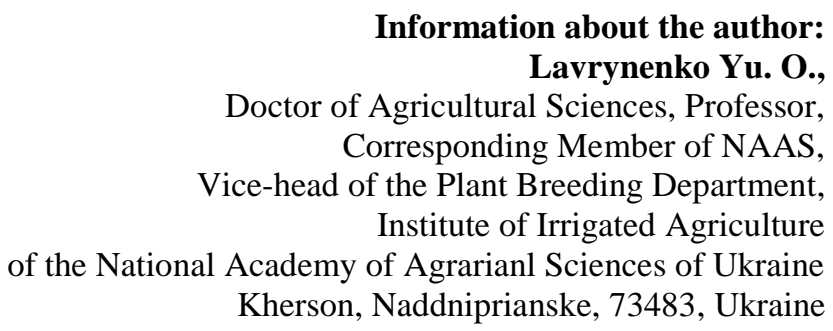

